\title{
Advances in the chemistry of thiazolidinediones as antidiabetic agents ${ }^{\dagger}$
}

\author{
Narendra Nath Ghosh ${ }^{a}$, Dipti Gupta ${ }^{a}$, Jyoti Chaudhary ${ }^{a}$, Sulekh Chand ${ }^{b}$, Sujata K. Dass ${ }^{c}$ and \\ Ramesh Chandra ${ }^{*}$
}

${ }^{a}$ Dr. B. R. Ambedkar Center for Biomedical Research, University of Delhi, Delhi-110 007, India

E-mail : acbrdu@hotmail.com Fax : 91-11-27666248

${ }^{b}$ Dr. Zakir Hussain College, University of Delhi, Delhi-110 002, India

${ }^{c}$ Department of Medicine, V. P. Chest Institute, University of Delhi, Delhi-10 007, India

Manuscript received 5 September 2003

\begin{abstract}
Several thiazolidinedione classes of compounds (drugs) found to be very effective in reducing insulin resistance or to efficiently potentiate insulin action in type 2 non insulin-dependent diabetes mellitus (NIDDM) patients; the structure-activity relationship of such related compounds, similar to ciglitazone, giving rise to the development of troglitazone, englitazone, pioglitazone and rosiglitazone as new drug entities for diabetes, and several studies showing that analogs of these classes interact with a nuclear receptor PPAR $\gamma$ and transcript the insulin sensitizing genes form the subject-matter of this review.
\end{abstract}

\section{Introduction}

The onset of insulin resistance in body, which causes an abnormal effect on glucose metabolism, is related not only to the development of type 2 diabetes but also to cardiovascular disease $^{1,2}$. A cluster of other metabolic abnormalities, involving body fat distribution, lipid metabolism, thrombosis and fibrinolysis, blood pressure regulation and endothelial cell function is referred to as the insulin resistance syndrome or the metabolic-syndrome. Since after the pioneering discovery of ciglitazone ${ }^{3}(1)$, a new class of thiazolidinedione based compounds has been developed to treat diabetic patients that can reverse the insulin resistance in non-insulin dependent diabetes mellitus (NIDDM) type 2 patients. Among various substituted benzyl-2,4-thiazolidinedione compounds, troglitazone ${ }^{4}(2)$, englitazone ${ }^{5}$ (3), pioglitazone ${ }^{6}(4)$ and rosiglitazone ${ }^{7}(5)$ are potentially antidiabetic compounds that have been clinically examined<smiles>CC1(COc2ccc(CC3SC(=O)NC3=O)cc2)CCCCC1</smiles>

1<smiles>O=C1NC(=O)C(Cc2ccc3c(c2)CCC(Cc2ccccc2)O3)S1</smiles>

3<smiles>Cc1c(C)c2c(c(C)c1O)CCC(C)(COc1ccc(CC3SC(=O)NC3=O)cc1)O2</smiles>

2<smiles>CCc1ccc(CCOc2ccc(CC3SC(=O)NC3=O)cc2)nc1</smiles><smiles>CN(CCOc1ccc(CC2SC(=O)NC2=O)cc1)c1ccccn1</smiles>

Chart 1

\footnotetext{
${ }^{\dagger}$ Dedicated to Professor S. M. Mukherji.
} 
(Chart 1). It has been reported that these drugs act as high-affinity ligand for peroxisome proliferator activated receptor gamma (PPAR $\gamma$ ), a receptor subtype to induce adipocyte differentiation ${ }^{8}$. It has also been reported that there<smiles>[R]N(C)CCOc1ccc(C=O)cc1</smiles>

6<smiles>[R][14CH2][14CH2]Oc1ccc(/C=C2\SC(=O)NC2=O)cc1</smiles>

(b)or(c)<smiles>[2H][13CH2]Oc1ccc(CC2SC(=O)NC2=O)cc1</smiles><smiles>CN(CCOc1ccc(CC2SC(=O)NC2=O)cc1)c1nc2ccccc2o1</smiles><smiles>CN(CCOc1ccc(CC2SC(=O)NC2=O)cc1)c1ccccn1</smiles>

10

Scheme 1a. Reagents : (a) 2,4-Thiazolidinedione, piperidine, acetic acid, toluene, reflux; (b) $\mathrm{H}_{2}, 10 \%$ Pd-C, (c) $\mathrm{Mg}$, methanol.

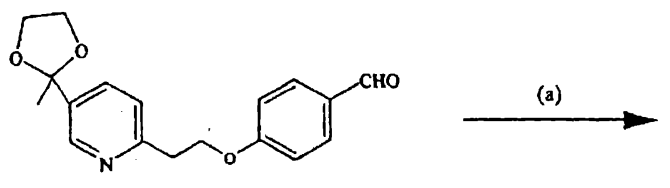

11<smiles>CC(C)c1ccc(CCOc2ccc(CC3SC(=O)NC(=O)C3Cc3ccc(OCCc4ccc(C5(C)OCCO5)cc4)cc3)cc2)nc1</smiles><smiles>CC1(c2ccc(CCOc3ccc(/C=C4\SC(=O)NC4=O)cc3)cc2)OCCO1</smiles>

12<smiles>CC(=O)c1ccc(CCOc2ccc(CC3SC(=O)NC3=O)cc2)nc1</smiles>

14<smiles>CCc1ccc(C(=O)COc2ccc(CC3SC(=O)NC3=O)cc2)nc1</smiles>

Scheme 1b. Reagents : (a) 2,4-Thiazolidinedione, piperidine. EtOH, heat; (b) $\mathrm{NaBH}_{4}, \mathrm{CoCl}_{2}$, dimethylglyoxime; (c) $2 \mathrm{~N}$-aqueous $\mathrm{HCl}$, heat.<smiles>CCOc1ccc(C=O)cc1</smiles>

Scheme 1c. Reagents : (a) 2,4-Thiazolidinedione, piperidine, benzoic acid, toluene, $\Delta, 57-95 \%$ yield; (b) $\mathrm{H}_{2}, 10 \%$ Pd-C, $70-96 \%$ yield. 
Ghosh et al. : Advances in the chemistry of thiazolidinediones as antidiabetic agents

is a significant positive relationship between PPAR $\gamma$ agonism in vitro and hypoglycemic activity of thiazolidinedione compounds in genetically diabetic mice ${ }^{9}$. Specifically, the thiazolidinediones improve insulin action and decrease insulin resistance. Treatment of insulin resistance type 2 diabetic patients with thiazolidinediones not only improves glycemic control and decreases insulin resistance, but also improves many of the abnormalities as part of the insulin resistance syndrome.

\section{Chemistry}

An aryl or heteroaryl substitution at the $C-5$ position of 2,4-thiazolidinedione moiety resulted in various biologically active metabolites, each having significant anti-diabetic or antihyperglycemic activities. 2,4-Thiazolidinediones substituted with an aryl or a heteroaryl substituent at $\mathrm{C}-5$ has been synthesized from an aryl or a hetroaryl aldehyde by its Knöevenagel condensation with a 2,4-thiazolidinedione, followed by their catalytic hydrogenation resulted in the corresponding racemic 5-substituted benzylthiazolidinediones, 8-10, 14-16 and 20, as shown in Schemes $1 \mathrm{a}, 1 \mathrm{~b}$ and $1 \mathrm{c}^{10-12}$.

A series of substituted pyridyl- and quinolinyl- containing 2,4-thiazolidinediones have been prepared and their euglycemic and hypolipidemic effects were compared with rosiglitazone 27 (maleate salt of BRL-49653) ${ }^{13}$. These compounds were prepared by Knöevenagel condensation reaction of 2,4-thiazolidinedione with aromatic aldehydes of suitably substituted pyridine and quinoline ring moieties respectively. The unsaturated thiazolidinediones thus obtained were further reduced to saturated thiazolidinediones (Scheme 2).
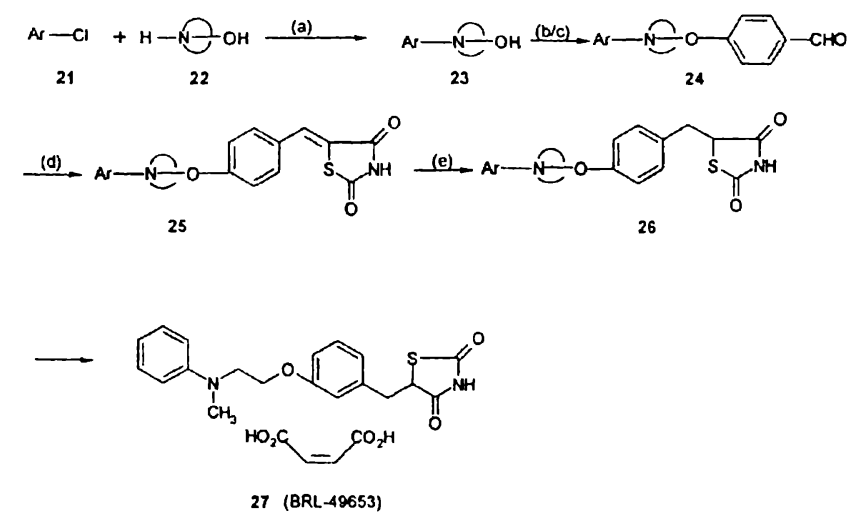

Scheme 2. Reagents : (a) Heat, $160^{\circ}, 50-100 \%$ yield; (b) 4 fluorobenzaldehyde, $\mathrm{NaH}, \mathrm{DMF}, 40-76 \%$ yield; (c) (i) methanesulfonyl chloride, triethylamine, $\mathrm{CH}_{2} \mathrm{Cl}_{2}, 83-90 \%$ yield, (ii) 4-hydroxybenzaldehyde, $\mathrm{K}_{2} \mathrm{CO}_{3}$, DMF, 80, 36 $45 \%$ yield; (d) 2,4-thiazolidinedione, piperidine, benzoic acid, toluene, $\Delta, 63-100 \%$ yield; (e) $\mathrm{Mg}-\mathrm{MeOH}, 48-65 \%$ yield.

Several imidazopyridine derivatives of 2,4-thiazolidinediones have been synthesized from their corresponding pyridines $^{14}$. Mitsunobu reaction ${ }^{15}$ of imidazopyridine derivative 31 with $\mathrm{N}$-protected 2,4-thiazolidinediones 32 gave compound 33. Removal of the protecting group, trityl, of 33 yielded the desired product 34 (Scheme 3 ).<smiles>Nc1ncccc1[N+](=O)[O-]</smiles>

28

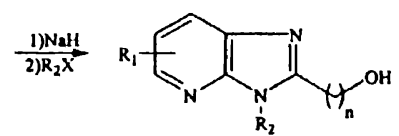

31

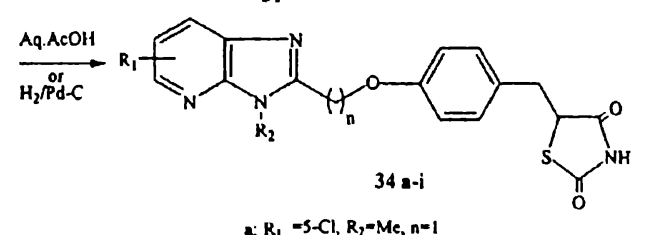

a: $R_{1}=5-C I, R_{2}-M e, n=1$

b: $R_{1}=-H_{1} R_{2}=M_{e}, n=1$

e: $R_{1}=H, R_{2}=M e, n=3$

d: $R_{1}-14, R_{2}-R_{1}, n=1$

e: $\mathrm{R}_{1}=\mathrm{H}, \mathrm{R}_{2}=4 . \mathrm{Ph}-\mathrm{C}_{6} \mathrm{H}_{4} \mathrm{CH}_{2}, \mathrm{n}=1$

f: $R_{1}=6-C l, R_{2}=M e, n=1$

$8: R_{1}=6-B r, R_{2}=M e, n=1$

$h: R_{1}=7-M e_{1} R_{2}-M e_{1} n=1$

i: $R_{1}=5,7$ dimthyl, $R_{2}=M e, n=1$

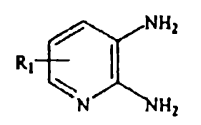

29
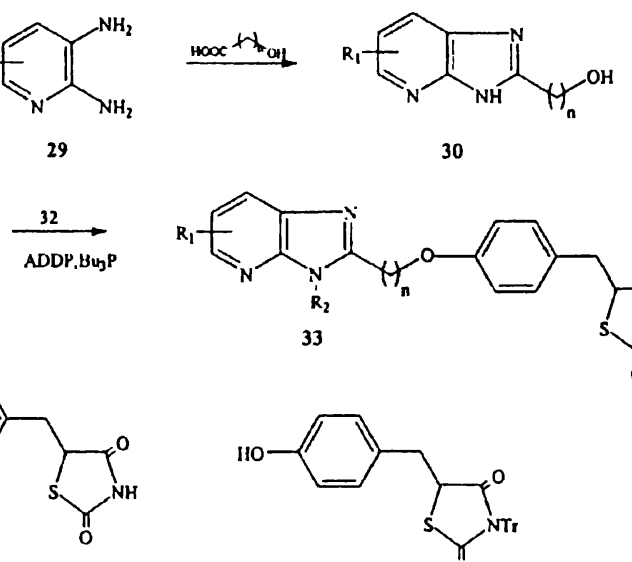

30
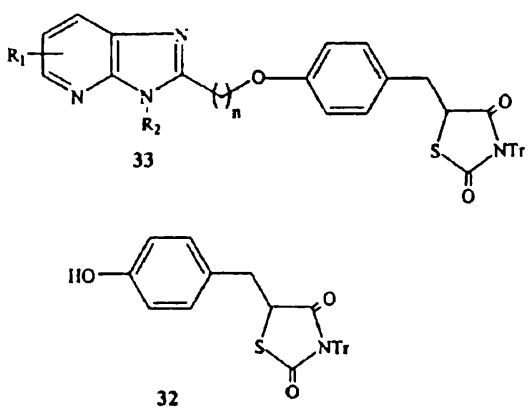

ADDP:Azodicarbonylidiperidine

Scheme 3 
A large number of 2,4-thiazolidinediones and 2,4oxazolidinediones with an $\omega$-(azoalkoxyphenyl) alkyl substituted at 5-position showed anti-diabetic effects in two genetically obese and diabetic animal models, $\mathrm{KKA}^{\mathrm{y}}$ mice and Wistar fatty rats. The anti-diabetic activities of the 2,4oxazolidinediones were found to be superior to those of 2,4thiazolidinediones. An asymmetric $\mathrm{O}$-acetylation of the corresponding alpha-hydroxy valerate with immobilized lipase, followed by cyclization of the oxazolidinedione ring led to formation of both enantiomers of 5-[3-[4-[2-(2-furyl)-5methyl-4-oxazolylmethoxy]-3-methoxyphenyl] propyl]-2,4oxazolidinedione (44). R-(+) 44 showed more potent glu- cose lowering activity than $\mathrm{S}(-)-(-) 44$ in $\mathrm{KKA}^{\mathrm{y}}$ mice. It also exhibited a 10 -fold more potent anti-diabetic activity than troglitazone in Wistar fatty rats ${ }^{16}$ (Scheme 4).

In earlier research publication, particularly research articles published from Takeda chemical industries, Japan, in 1982 onwards mostly by Sodha et al. ${ }^{3}$, the synthesis of the thiazolidine-2,4-dione (47) by the reaction of ethyl-2-chloro3[4-(2-substituted phenyl or 2-alkoxy-5-pyridyl propoxy) phenyl] propionate with thiourea followed by acid hydrolysis was presented (Scheme 5).

These workers also showed the preparation of compound 49 by the following method (Schemes 6,7).

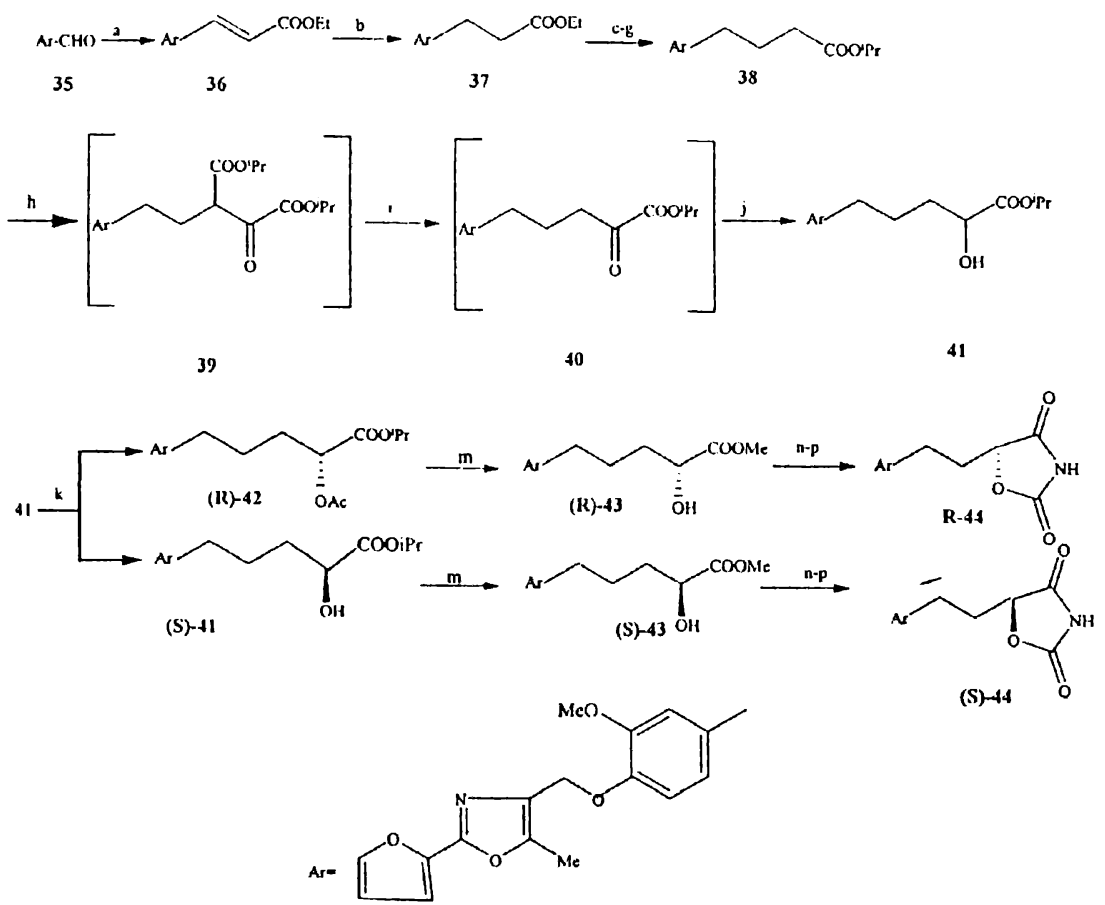

Scheme 4. Reagents : (a) $\mathrm{NaH}, \mathrm{EtO}_{2} \mathrm{CCH}_{2} \mathrm{CO}_{2} \mathrm{P}(\mathrm{O})(\mathrm{OEt})_{2}, \mathrm{DMF}$; (b) $\mathrm{H}_{2}, \mathrm{Pd}-\mathrm{C}, \mathrm{AcOEt} ;$ (c) $\mathrm{NaBH}_{4} \cdot \mathrm{MeOH}, \mathrm{THF}$; (d) $\mathrm{MsCl}, \mathrm{Et}{ }_{3} \mathrm{~N}, \mathrm{AcOEt}$; (e) $\mathrm{NaCN}$, DMF; (f) aqueous KOH, 2-methoxyethanol; (g) $\mathrm{K}_{2} \mathrm{CO}_{3},{ }^{i} \mathrm{Pr}-\mathrm{I}, \mathrm{DMF}$; (h) $\mathrm{NaH},\left(\mathrm{CO}_{2}{ }^{\mathrm{i}} \mathrm{Pr}\right)_{2}, \mathrm{PhMe}, \mathrm{DMF}$; (i) $\mathrm{NaCl}, \mathrm{DMSO}$; (j) $\mathrm{NaBH}_{4}, \mathrm{THF}$, ${ }_{-} \mathrm{PrOH}$; (k) immobilized lipase (LIP-301), MS-4A, vinyl acetate, $\mathrm{PhMe}$; (m) $\mathrm{HCl}-\mathrm{MeOH} ;(\mathrm{n}) \mathrm{ClCO}_{2} \mathrm{C}_{6} \mathrm{H}_{4}\left(p-\mathrm{NO}_{2}\right)$, pyridine; (o) $\mathrm{NH}_{3}$ gas, THF; (p) $\mathrm{DBU}, \mathrm{CHCl}_{3}$.

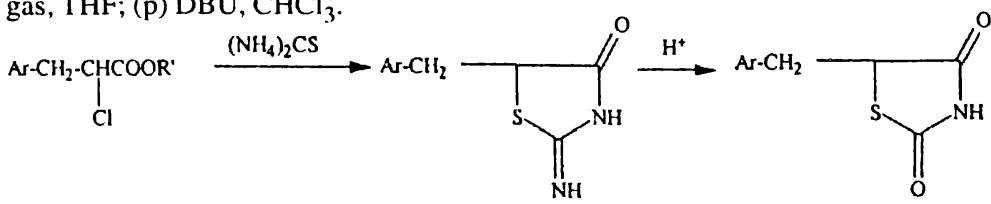

45

46

47

$\mathrm{Ar}=$ Substituted phenyl, 2-alkoxy-5-pyridyl

Scheme 5

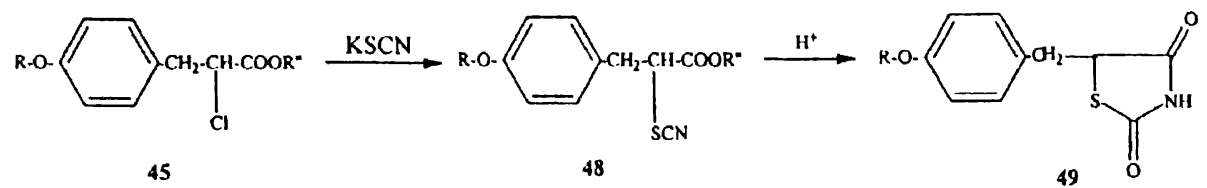

Scheme 6 
Ghosh et al. : Advances in the chemistry of thiazolidinediones as antidiabetic agents

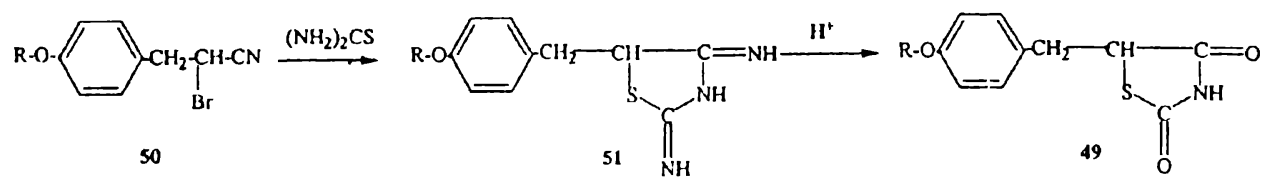

Scheme 7

A new strategy for the discovery of a second generation of 2,4-thiazolidinedione euglycemics with novel structural features and greatly improved potency has been achieved by replacing the ether function of englitazone with various functional groups, i.e. ketone, alcohol or olefin moiety. These compounds were found to lower blood glucose levels in genetically obese and insulin resitant ob/ob mice ${ }^{17-19}$. The replacement of the ether oxygen of the 2-benzylbenzopyran (3) moiety by sulphur and substituted nitrogen were found to be somewhat inferior in the potency while the replacement by the carbonyl group showed improved potency (Table 1). The tetralone (52) showed no potency advantanges over the open chain ketone (53). In addition, in the benzopyran series, the stereogenicity at C-2. of the benzopyran ring of (3) has been' shown to have little influence over its euglycemic potency. A greater in-vivo potency $50-100$ ford ' improvement over englitazone) has been shown by compound (54) (CP-86325) containing 5'-methyl-2-phenyl-4-" oxazolyl tail in carbonyl containing thiazolidinedione ${ }^{20}$.
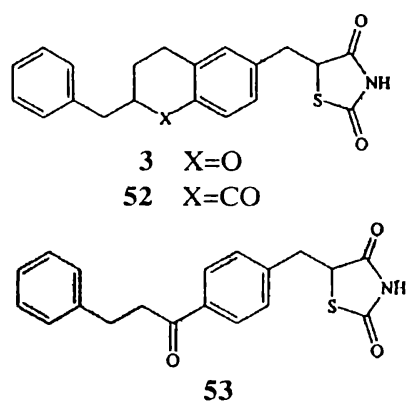

Table 1. Euglycemic activity of ketones vs ether

\begin{tabular}{cccc} 
Compd. & \multicolumn{4}{c}{ \% Glucose normaluzation in ob/ob mouse $(\mathrm{mg} / \mathrm{kg})^{a}$} \\
\cline { 2 - 3 } 3 & 25 & 10 & 5 \\
52 & $91^{b}$ & $70^{b}$ & $48^{b}$ \\
53 & $47^{b}$ & 54 & $39^{b}$ \\
& $93^{b}$ & $81^{c}$ & $53^{d}$
\end{tabular}

${ }^{a}$ Normalization $(100 \%)$ = ciglitazone effect at $50 \mathrm{mg} / \mathrm{kg},{ }^{b} \mathrm{p}<0.05$ when

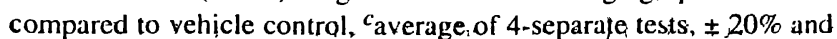

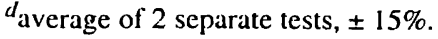

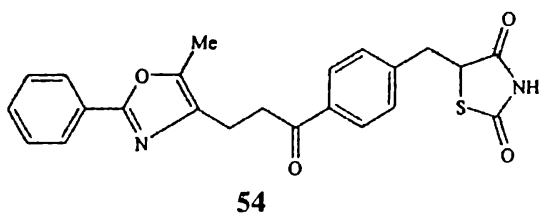

Variation of the substituents on the thiazolidinedione heterocycle led to the identification of the naphthalene ring as the optimal group for eliciting antihyperglycemic activity within the series of 5-sulfonyl-2,4-thiazolidinediones. Thus, 5-(2-naphthalenyl sulfonyl)-2,4-thiazolidine (55) [AY$31,637]$ was found to be equipotent to ciglitazone in two animal models of NIDDM. These pharmacologically active sulfones were synthesized ${ }^{21}$ by a novel selective C-5 sulfonylation of dilitho-2,4-thiazolidinedione with appropriate sulfonyl chloride and attachment of the 5-sulfonyl 2,4thiazolidinedione moiety to the 2-naphthalene.<smiles>O=C1NC(=O)C(C(=O)Oc2ccc3ccccc3c2)S1</smiles>

Some oxathiadiazoles of various bicyclic heterocycles and carbocycles also showed potent antihyperglycemic activities in insulin resistant obese Zucker (fa/fa) rats. Thus, in a series of $3 H-1,2,3,5$-oxathiazole-2-oxides, particularly 4-[(2-naphthalenyl)methyl]-3H-1,2,3,5-oxathiadiazole-2oxide (56) (AY-30,711) was found to be approximately five times as potent as ciglitazone ${ }^{22}$.

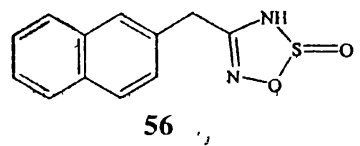

The condensation of 5-(4-aminobenzyl)thiazolidine-2,4diones with (R)-2-phenylpropionic acid using 1-hydroxybenzotriazole and 1-ethyl-3-(3-dimethylaminopropyl) carbodiimide hydrochloride in DMF led to $57\left[R^{1} R^{2} R^{3} C\right.$ $\mathrm{A}=(\mathrm{R})-\mathrm{PhMeCHCONH}$ ] which at $100 \mathrm{mg} / \mathrm{kg}$ p.o. in vivo lowered $54 \%$ blood sugar in mice ${ }^{23}$.

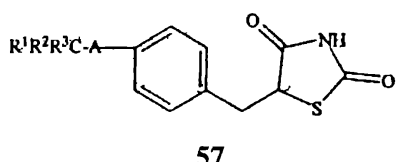

Several benzofuran containing thiazolidinediones has been shown to enhance the insulin sensitizing activity in type 2 diabetic patients which has been prepared by the condensation of the 2-aroyl-5-formylbenzofuran with 2,4thiazolidinedione gave the benzofuran $\left[X=O ; R R^{1}=\right.$ bond] which was reduced to $58\left[X=O, H_{2} ; R=R^{1}=H\right]^{24}$. 


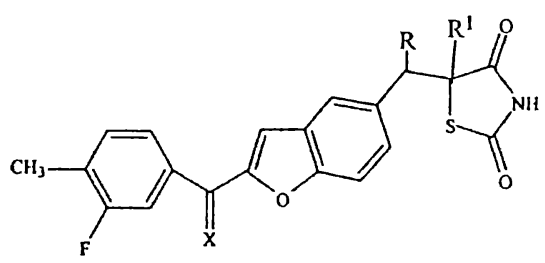

58

The reaction of 4-[2-(oxo-3,4-dihydro- $2 \mathrm{H}-1,3-$ benzoxazin-3-yl)ethoxy]benzaldehyde with 2,4thiazolidinedione in the presence of a catalytic amount of acetic acid and piperidine in toluene followed by hydrogenation of the resulting thiazolidinedione (59) over $10 \% \mathrm{Pd} /$ $\mathrm{C}$ in 1,4-dioxan afforded 5-\{4-[2-(4-oxo-3,4-dihydro- $2 \mathrm{H}$ 1,3-benzoxazin-3-yl)ethoxy]phenyl \}methyl thiazolidine-2,4dione $(60)$ which showed $65.8 \%$ blood glucose reduction at $9.8 \mathrm{mg} / \mathrm{kg} / \mathrm{day}^{25}$.

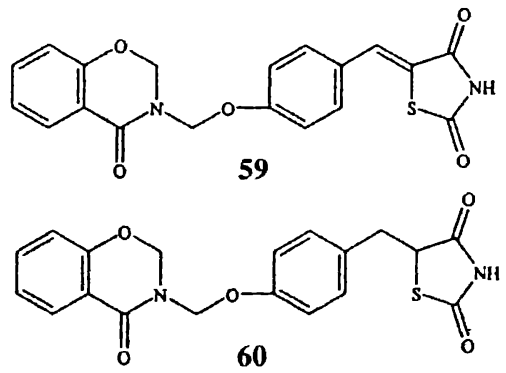

The thiazolidinedione 61 (the dotted lines a single bond, a double bond) having the thiazolidinedione ring residue linked to either of 2-, 3-, 4-, 5- and 6-positions on the indole rings, have been shown to exhibit excellent effects of reducing blood sugar level and reducing the lipid concentration in blood, and accordingly are useful as therapeutic agents for treating diabetes mellitus ${ }^{26}$.

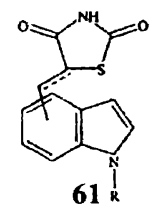

The addition of concentrated hydrochloric acid and acetic acid in 3-methoxy-carboxymethyl-5-(4-methylene) thiazolidine-2,4-dione resulted in the titled compound (62) $\left[\mathrm{X}=\mathrm{O} ; \mathrm{R}^{1}=4\right.$-tolyl) in $96 \%$ yield. The latter compound and $62\left(\mathrm{R}^{\mathrm{l}}=\mathrm{Q} ; \mathrm{X}=\mathrm{O}\right)$ in vitro showed $\mathrm{IC}_{50}$ of $2.5 \times 10^{-8}$ and $1.5 \times 10^{-9} M$, respectively, against aldose reductase. These compounds were administered p.o. to rats having diabetic condition induced by steptozotocin, resulting in lowering sorbitol content in erythrocytes and sciatic nerve and increasing sciatic nerve transmission ${ }^{27}$.<smiles>[X]c1c(Cl)sc(=O)n1C(=O)O</smiles>

The hyperglycemics and aldose reductase inhibitors of indolylthiazolidinediones $(63)$ were prepared by the condensation of thiazolidine2,4-dione with 5-formyl unsubstitute or substituted indoles ${ }^{28}$.<smiles>O=C1NC(=O)/C(=C/c2ccc3c(c2)CCN3)S1</smiles>

The thiazolidinediones 64 (ring $\mathrm{A}=$ imidazolyl, tetrazolyl, $\mathrm{Q}, \mathrm{Q}^{1}$; wherein $\mathrm{X}=\mathrm{O}, \mathrm{S}, \mathrm{NH} ; \mathrm{Y}=\mathrm{N} ; \mathrm{R}^{1}=\mathrm{H}$, halo, lower alkyl, lower hydroxy alkyl, lower alkoxy, $\mathrm{CF}_{3}, \mathrm{NO}_{2}, \mathrm{COOH}$, lower alkoxy carbonyl, $\mathrm{CH}_{2} \mathrm{NHCONHCONHCOOR}^{5}, \mathrm{C}: \mathrm{NOH}$; wherein $\mathrm{R}^{5}=\mathrm{H}$, lower alkyl; $\mathrm{R}^{2}, \mathrm{R}^{3}=\mathrm{H}$, halo; $\mathrm{R}^{4}=\mathrm{H}, \mathrm{OH} ; \boldsymbol{n}=0,1$ ) were found to lower blood sugar, based on the enhancement of insulin sensitivity and have been found useful as anti-diabetics for treating or preventing non-insulin-dependent diabetes and various diabetes complications ${ }^{29}$.

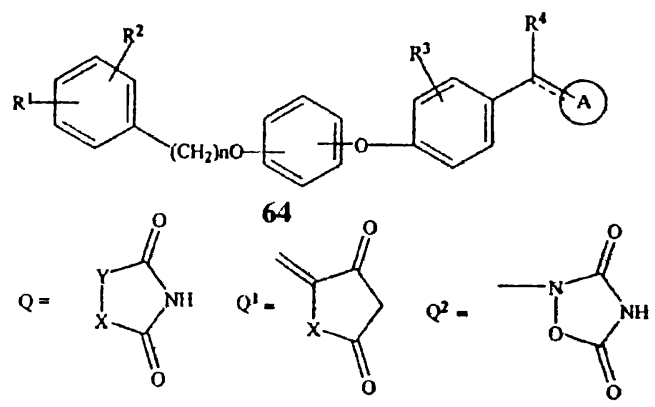

Several oxime-containing thiazolidinediones have been found to be useful for treating or preventing hyperlipidemia, hyperglycemia, obesity, impaired glucose tolerance (IGT), insulin resistnat non-IGT(NGT), non-diagnostic GT, insulin resistance, diabetic complications, fatty liver, polycystic ovary syndrome (PCOS) and gestational diabetes mellitus (GDM); in addition, they have aldose reductase inhibitory activity. One of these oxime-containing thiazolidinediones, particularly the compound 65 at $1 \mathrm{mg} / \mathrm{kg}$ orally in hyperglycemic mice reduced blood glucose by $49.3 \%$ after $3 \mathrm{~h}^{30}$

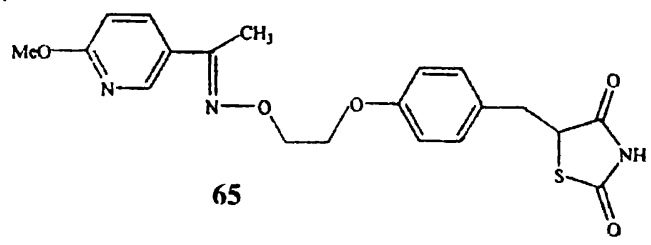


Ghosh et al. : Advances in the chemistry of thiazolidinediones as antidiabetic agents

A number of imidazolyl thiazolidinedione derivatives 66 have been prepared and found to be active insulin resistant improving agents, 5-lipoxygenase inhibitors and peroxidized fat formation restrainer ${ }^{31}$.

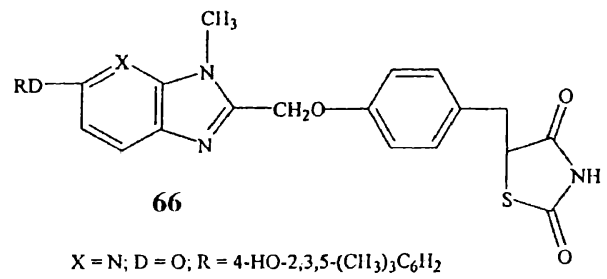

Several quinolinyl azolidinediones derivatives were also found to lower the blood sugar level, among one of them known as 5-[[7-(4-triflouromethylbenzyloxy)-3quinolyl]methyl]thiazolidine-2,4-dione 67 when administered to mice at $30 \mathrm{mg} / \mathrm{kg} / \mathrm{day}$ p.o. for three consecutive days, lowered the blood glucose level to $56 \%$ of the control $^{32}$.

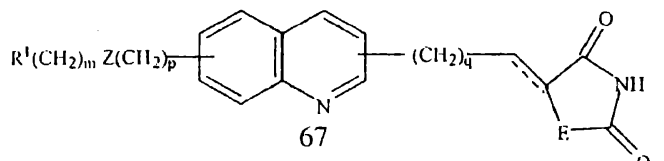

$\mathrm{R}^{1}=\mathrm{H}, \mathrm{C}_{1}-\mathrm{C}_{6}$ alkyl etc; $\mathrm{z}=\mathrm{O}, \mathrm{S}, \mathrm{CO}$ or $\mathrm{CH}_{2} ; \mathrm{m}, \mathrm{p}, \mathrm{q}=$ an integer of 0 4; $\mathrm{E}=\mathrm{S}$ or $\mathrm{O}$

Some new methods of preparation of 5-(halo or alkyl)5-aryl-2,4-thiazolidinedione and oxazolidinedione derivatives have been reported by several research workers of Merck \& Co., Inc., U.S.A. in $2000^{33}$. All these compounds (68-70) have been found to be useful in the treatment, control or prevention of diabetes, hyperglycemia, hyperlipidemia (including hyperchloesterolemia and hypertriglyceridemia), artherosclerosis, obesity, vascular restenosis and PPAR $\gamma$ and/ or $\gamma$ mediated diseases, disorders and conditions.<smiles>O=C1NC(=O)C(F)(c2cccc(OCCCOc3ccc(Oc4ccccc4)cc3CCCl)c2)S1</smiles><smiles>CCCc1cc(C2CCCCC2)ccc1OCCCOc1cccc(C2SC(=O)NC2=O)c1</smiles><smiles>CCCc1cc(Oc2ccccc2)ccc1OCCCOc1cccc(C2SC(=O)NC2=O)c1</smiles>

Flavonoid linked thiazolidinediones also showed antidiabetic activities ${ }^{34}$. Thiazolidinedionyl-benzopyrans including flavonoid $71\left(\mathrm{R}=3,4\right.$-dihydroxyphenyl, $\mathrm{R}^{5}=\mathrm{R}^{7}=\mathrm{OH}$, $\mathrm{R}^{6}=\mathrm{R}^{8}=\mathrm{H}$ ) has been prepared in four steps synthetic sequence starting from rutin, 4-hydroxybenzaldehyde and 1,3dibromopronane.<smiles>[R]c1c([R])c([R])c2c(c1[Y4])OC([R])C(OCCCOc1ccc(CC3SC(=O)NC3=O)cc1)C2=O</smiles>

A new flavone derivative 4'-flavonyl-2,4-thiazolidinedione (72) has also been found to be potential antidiabetic agent $^{35}$.<smiles>O=C1NC(=O)C(Cc2ccc(-c3cc(=O)c4ccccc4o3)cc2)S1</smiles>

\section{Effect of thiazolidinediones}

Thiazolidinediones (TZDs) are oral antidiabetic drugs that selectively enhance or partially mimic certain effects of insulin on carbohydrate and lipid metbolism in type 2 diabetes mellitus, thus acting as insulin sensitizer. Diabetes being a metabolic disorder, there is uncertainty regarding primary lesion but research done in this area suggest that defects occur in liver, peripheral target tissues and the pancreatic $\beta$-cells ${ }^{36,37}$. A characteristic trait of type 2 diabetes mellitus is over production of glucose by liver and second defect occurs at the level of peripheral target tissue. Glucose up take is usually increased in skeletal muscle but this insulin stimulated activity gets significantly reduced in type 2 diabetes mellitus patients.

All members of TZDs family have more or less similar effects on carbohydrate and lipid metabolism. Their effects are dose-dependent with maximal efficacy produced by dosages ranging from $<1 \mathrm{mg} / \mathrm{kg} / \mathrm{day}$ to $50 \mathrm{mg} / \mathrm{kg} / \mathrm{day}{ }^{38-4 I}$. TZDs cause substantial reduction in hyperglycemia and hyperinsulinemia in genetically diabetic obese model, indicating reduced insulin resistance. This has been confirmed by experiments conducted on diabetic rat model, which were fed fat and fructose rich diet ${ }^{40,42-44}$. In severely insulin dependent diabetic states induced by streptozotocin, TZDs have little or no effect on hyperglycemia confirming the fact that their glucose lowering activity is dependent on the presence 
of insulin ${ }^{45-47}$. TZDs also reduce the concentration of triglyceride and free fatty acids (FFA) in diabetic/non-diabetic animals and this effect is independent of glucose or insulin lowering effect ${ }^{38,43,48-50}$. This effect has been attributed to decreased hepatic VLDL (very low-density lipid) synthesis and increased peripheral clearance, together with reduced lipolysis $38,40,50,51$. While TZDs in general do not directly modulate insulin secretion in islet cells, the amelioration of insulin resistance exerts insulin-sparing effects, reducing elevation in insulin levels. In diabetic animals, this can restore responsiveness of desensitized islets to insulinotropic stimuli. This is exemplified by troglitazone that produced a marked regranulation of pancreatic islets in several diabetic $\mathrm{db} / \mathrm{db}$ mice ${ }^{52}$.

Although there is little published information on adverse effects in animals, long term use of TZDs can cause fluid retention, cardiac hypertrophy, haemodilution and anaemia in rodents and $\operatorname{dog} s^{52}$. Recently clinical trials of severe hepatoxicity associated with troglitazone have also been reported $^{54,55}$.

\section{Course of action}

Resistance to stimulatory effect of insulin on glucose utilization is a key pathogenic feature of type 2 diabetes mellitus and other diseases like obesity and insulin resistance syndrome (characterized by insulin resistance, dyslipidemia, hypertension and an increased risk of cardiovascular disease). Studies with either type 1 or 2 diabetes mellitus indicated that the defect lies at the level of glucose transport or glucose phosphorylation ${ }^{56-58}$. But later work done by Cline and coworkers on the skeletal muscle demonstrated that impaired glucose transport is responsible for insulin resistance ${ }^{59}$. There are two distinct molecular fami-

Table 2. Glucose transporters and their characteristics

\begin{tabular}{|c|c|c|}
\hline Transporter & Tissue distribution & Characteristics \\
\hline GLUT-1 & $\begin{array}{l}\text { Widely expressed, high } \\
\text { concentration in brain, } \\
\text { erythrocytes and endothelial cells }\end{array}$ & $\begin{array}{l}\text { Constitutive glucose } \\
\text { transporter }\end{array}$ \\
\hline GLUT-2 & $\begin{array}{l}\text { Kidney, small intestine epithe- } \\
\text { lia, liver, pancreatic } \beta \text { cells }\end{array}$ & $\begin{array}{l}\text { Low affinity glucose } \\
\text { transport, has role } \\
\text { in sensing glucose } \\
\text { concentration in is- } \\
\text { lets }\end{array}$ \\
\hline GLUT-3 & Neurons, placenta & $\begin{array}{l}\text { High affinity for } \\
\text { glucose }\end{array}$ \\
\hline GLUT-4 & $\begin{array}{l}\text { Skeletal muscle, cardiac } \\
\text { muscle and adipose cells }\end{array}$ & $\begin{array}{l}\text { Responds to insulin } \\
\text { for transport }\end{array}$ \\
\hline GLUT-5 & $\begin{array}{l}\text { Small intestine, sperm, kidney, } \\
\text { brain, adipose cells, muscle }\end{array}$ & $\begin{array}{l}\text { Fructose transporter, } \\
\text { very low affinity } \\
\text { for glucose }\end{array}$ \\
\hline
\end{tabular}

lies of cellular transporters of glucose and other hexoses ${ }^{60,61}$. One group of transporters actively transports glucose but other conveys glucose by the means of facilitated diffusion. This group consists of five homologous transmembrane proteins, GLUT-1, 2, 3, 4 and 5 that are encoded by distinct genes (Table 2).

GLUT-4 is considered most important transporter for glucose and the studies indicate that TZDs restores the expression and translocation of GLUT-4 in adipocyte ${ }^{60-63}$. They also overcome the tumor necrosis factor (TNF $\alpha$ ) induced inhibition of insulin stimulated glucose transport in adipocytes ${ }^{64}$. But TZDs do not restore defective insulin stimulated GLUT- 4 translocation as shown by studies on muscle of insulin-resistant Zucker rats ${ }^{65}$.

\section{Mechanism of action}

By now, it is evident that TZDs improve metabolic control in patients with type 2 diabetes through the improvement of insulin sensitivity. TZDs exert their antidiabetic effect through a mechanism that involves activation of gamma isoform of peroxisome proliferator activated receptor (PPAR), which consequently stimulates certain transcriptional events ${ }^{66,67}$. These PPARs belong to the steroid/thyroid/retinoid receptor superfamily, like liver $X$ receptors (LXRs) and are nuclear lipid-activable that control a variety of genes in several pathways of lipid metabolism ${ }^{68,69}$. Three related PPAR isotypes ( $\alpha, \beta$ and $\gamma$ ) have been identified in vertebrates including Xenopus, mouse, rat, hamster and human ${ }^{70-81}$. Although TZDs act as ligand for all isotypes, it is the PPAR $\gamma$ through which they regulate lipid metabolism. White and brown adipose tissues are the major sites for PPAR $\gamma$ expression ${ }^{82}$ where it is complexed with retinoid $X$ receptor (RXR) within the nucleus ${ }^{83-86}$. TZDs are lipoproteins and thus have high affinity for adipocytes. This causes conformational changes in PPAR $\gamma$-RXR complex, which displaces a co-repressor and allows activation of regulatory sequences of DNA, which in turn controls expression of specific genes. Some of these genes are also controlled by insulin and thus in this way they can mimic genomic effects of insulin to certain extent. TZDs also influence the enzymes of lipid metabolism such as lipoprotein lipase (LPL), fatty acid transporter protein (FATP), adipocyte fatty acid binding (APZ) and phosphophenolpyruvate carboxykinase (PEPCK) ${ }^{84}$. Since PPAR $\gamma$ plays a key role in adipogenesis and is the receptor for insulin-sensitizing drugs, regulation of its expression with respect to nutrition, obesity and diabetes has been studied widely. In vitro exposure of isolated adipocytes to insulin and corticosteroids synergistically induce PPAR $\gamma \mathrm{mRNA}^{87}$. Pioglitazone also enhances the adipocyte differentiation ${ }^{88}$. 
Ghosh et al. : Advances in the chemistry of thiazolidinediones as antidiabetic agents

In contrast, PPAR $\gamma$ is down regulated by TNF $\alpha$, which triggers dedifferentiation of mature adipocytes ${ }^{89,90}$. Studies also indicate that PPAR $\gamma$ get increased in both obese nondiabetic and type 2 diabetes mellitus patients in direct relation to body mass index and fasting insulinemia, suggesting that abnormalities of PPAR $\gamma$ might be involved in skeletal muscle insulin resistance linked to obesity and diabetes ${ }^{90,91}$. TZDs effectively promote the conversion of pre-adipocytes into adipocytes ${ }^{91}$. Thus, the cellular mechanism by which TZDs exactly increase the glucose uptake in muscle in vivo is still uncertain.

\section{References}

1. O. G. Kolterman, R. S. Gravy, J. Griffin, P. Burstein, J. Insel, J. A. Scarlett and J. M. Olefsky, J. Clin. Invest., 1981, 68, 957.

2. J. M. Olefsky, T. Garvey, R. Henry, D. Brillon, S. Matthaei and G. R. Freidenberg, Am. J. Med., 1988, (suppl. 5A), 86.

3. T. Sodha, K. Mizuno, H. Tawada, Y. Sugiyama, T. Fujita and Y. Kawamatsu, Chem. Pharm. Bull., 1982, 30, 3563; T. Sodha, K. Mizuno, E. Imamiya, Y. Sugiyama, T. Fujita and Y. Kawamatsu, Chem. Pharm. Bull. 1982, 30, 3580; T. Sodha, K. Mizuno and Y. Kawamatsu, Chem. Pharm. Bull., 1984, 32, 4460.

4. T. Yoshioka, T. Fujita, T. Kanai, Y. Aizawa, T. Kurumada, K. Hasegawa and H. Horikoshi, J. Med. Chem., 1989, 32, 421; T. Fujiwara, A. Okuno, S. Yoshioka and H. Horikoshi, Metabolism, 1995, 44, 486.

5. D. A. Clark, S. W. Goldstein, R. A. Volkmann, J. F. Eggler, G. F. Holland, B. Hulin, R. W. Stevenson, D. K. Kreutter, E. M. Gibbs, M. N. Krupp, P. Merrigan, P. L. Kelbaugh, E. G. Andrews, D. L. Trickner, R. T. Suleske, C. H. Lamphere, F. J. Rajeckas, W. H. Kappeler, R. E. McDermott, J. N. Huston and M. R. Johnson, J. Med. Chem., 1991, 34, 319.

6. Y. Momose, K. Meguro, H. Ikeda, C. Hatanaka, S. Oi and T. Sohda, Chem. Pharm. Bull., 1991, 39, 1440.

7. B. C. C. Cantello, M. A. Cawthorne, D. Haigh, R. M. Hindley, S. A. Smith and P. L. Thurlby, Biomed. Chem. Lett., 1994, 4, 1181 .

8. J. M. Lehman, L. B. Moore, T. A. Smith-Oliver, W. O. Wilkison, T. M. Willson and S. A. Kliewer, J. Biol. Chem., 1995, 270, 12953.

9. J. Berger, P. Bailey, C. Biswas, C. A. Cullinan, T. W. Doebber, N. S. Hayes, R. Saperstein, R. G. Smith and M. D. Leibowitz, Endocrinology, 1996, 137, 4189; T. M. Willson, J. E. Cobb, D. J. Cowan, R. W. Wiethe, I. D. Correa, S. R. Prakash, K. D. Beck, L. B. Moore, S. A. Kliewer and J. M. Lehmann, J. Med. Chem., 1996, 39, 665.

10. B. C. C. Cantello, M. A. Cawthorne, G. P. Cotton, P. T Duff, D. Haigh, R. H. Hindley, C. A. Lister, S. A. Smith and P. L. Thurlby, J. Med. Chem., 1994, 37, 3977.

11. S. P. Tanis, T. T. Parker, J. R. Colca, R. M. Fisher and R. F. Kletzein, J. Med. Chem., 1996, 39, 5053.

12. B. B. Lohray, V. Bhushan, B. P. Rao, G. R. Madhvan, N. Murali, K. N. Rao, A. K. Reddy, B. M. Rajesh, P. G.
Reddy, R. Chakrabarti, R. K. Vikramadityan, R Rajagopalan, R. N. V. S. Mamidi, H. K. Jajoo and S. Subramaniam, J. Med. Chem., 1998, 41, 1619.

13. B. B. Lohray, V. Bhushan, A. S. Reddy, P. B. Rao, N. J. Reddy, P. Harikishore, N. Haritha, R. K. Vikramadityan, R. Chakrabarti, R. Rajagopalan and K. Katneni, J. Med. Chem., 1999, 42, 2569.

14. M. Oguchi, K. Weda, H. Honma, A. Tanaka, T. Kaneko, S. Sakahibara, J. Ohsumi, N. Serizawa, T. Fujiwara, H. Horikashi and T. Fujita, J. Med. Chem., 2000, 43, 3053.

15. O. Mitsunobu, Synthesis, 1981, 1.

16. Y. Momose, T. Maekawa, T. Yamano, M. Kawada, H. Odaka, H. Ikeda and T. Sodha, J. Med. Chem., 2002, 45, 1518.

17. Y. Kawamatsu and T. Fujita, Eur Pat., EP $84926 / 1983$ (Chem. Abstr., 1983, 99, 212516).

18. D. A. Clark, S. W. Goldstein, R. A. Volkmann, J. F. Eggler, G. F. Holland, B. Hulin, R. W. Stevenson, D. K. Kreutter, E. M. Gibbs, M. N. Krupp, P. Merrigan, P. L. Kelbaugh, E. G. Andrews, D. L. Tickner, R. T. Suleske, C. H. Lamphere, F. J. Rajeekas, W. H. Kappler, R. E. McDermott, N. J. Huson and M. R. Johnson, J. Med. Chem., 1991, 34, 319.

19. R. L. Dow, B. M. Bechle, T. T. Chou, D. A. Clark, B. Hulin and R. W. Stevenson, J. Med. Chem., 1991, 34, 1538.

20. B. Hulin, D. A. Clark, S. W. Goldstein. R. E. McDermott, P. J. Dambek, W. H. Kappler, C. H. Lamphere, D. M. Lewis and J. P. Rizzi, J. Med. Chem., 1992, 35, 1853.

21. A. Zask. I. Jirkovsky and M. L. McCaleb, J. Med. Chem., 1990, 33, 1418.

22. J. W. Ellingboc, T. R. Alessi, T. M. Dolak, T. T. Nguyen, J. D. Tomer, F. Guzzo, J. F. Bagli and M. L. McCaleb, J. Med. Chem., 1992, 35, 1176.

23. S. Taira and A. Sugimoto, PCT Int., WO 9732863/1997 (Chem. Abstr., 1997, 127, 248106).

24. B. E. Huff, C. L. Leffelman, M. E. LeTourneau, K. A. Sullivan, J. A. Ward and J. R. Stille, Heterocycles, 1997, 45, 1363 (Chem. Abstr., 1997, 127, 205507).

25. Y. Nagao, Y. Ito, J. Kotake, T. Kouda, H. Honda, S. Sato and H. Matsuda, Eur. Pat., EP $787727 / 1997$ (Chem. Abstr:, 1997, 127, 205585).

26. M. Ogawa, T. Morita, N. Iibuchi and H. Tsutsui, Eur. Pat., EP 780389/1997 (Chem. Abstr., 1997, 127, 135790).

27. A. Sulimoto, S. Matsui, M. Taira and T. Ushijima, Japan Pat., JP 08109174/1996 (Chem. Abstr., 1996, 125, 86632).

28. Y. Ohara, M. Suzuki, K. Ohdoi, N. Miyachi, K. Kato, T. Kobayashi, K. Shikada, M. Kitahara and T. Naito et al., PCT Int., WO 9626207/1996 (Chem. Abstr., 1996, 125, 275859).

29. K. Niigata, T. Takahashi, T. Maruyama, T. Suzuki, K. Onda, T. Konya and O. Noshiro, Japan Pat., JP 0859638/ 1996 (Chem. Abstr., 1996, 125, 10826). 
30. H. Yanagisawa, T. Fujita, K. Fujimoto, T. Yoshioka, K. Wada, M. Oguchi, T. Fujiwara and H. Horikoshi, Eur. Pat., EP 708098/1996 (Chem. Abstr., 1996, 125, 58495).

31. T. Fujita, K. Wada and T. Fujiwara, Japan Pat., JP 351769/ 2000 (Chem. Abstr., 2001, 134, 56664).

32. Y. Nomura, S. Sakuma and S. Masui, PCT Int., WO 9612719/1996 (Chem. Abstr., 1996, 125, 114599).

33. S. P. Sahoo, C. Santini, J. K. Boueres, J. V. Heck, E. Metzger and V. K. Lombardo, PCT Int., WO $0078321 /$ 2000 (Chem. Abstr, 2001, 134, 715589); S. P. Sahoo, J. P. Bergman, V. K. Lombardo, E. Metzger and H. Koyama, PCT Int, WO 0078313/2000(Chem. Abstr., 2001, 134, 71590); M. H. Kress, G. W. Chiu, M. D. Weingarten and J. McNamara, PCT Int., WO 00078314/2000 (Chem. Abstr., 2001, 134, 71591).

34. H. A. Pershadsingh and M. A. Avery, US Pat., 6028088/ 2000 (Chem. Abstr., 2000, 132, 166059).

35. O. Bozdag, E. J. Versphohl and R. Ertan, Arz-Forsch, 2000, 50, 539 (Chem. Abstr., 2000, 133, 237715).

36. A. R. Saltiel and J. M. Olefsky, Diabetes, 1996, 45, 1661.

37. A. Consoli, Diabetes Care, 1992, 15, 430.

38. T. Fujiwara, S. Yoshioka, T. Yoshioko, T. Ushiyama and H. Horikoshi, Diabetes, 1988, 37, 1549.

39. H. Ikeda, S. Taketomi, Y. Sugiyama, Y. Shimura, T. Sohda and K. Meguro, Arz-Forsch/Drug Res., 1990, 40, 156.

40. N. D. Oakes, C. J. Kennedy, A. B. Jenkins, D. R. Laybuff, D. J. Chrisholm and E. W. Kraegen, Diabetes, 1994, 43, 1203.

41. A. Y. Chang, B. M. Wyse and B. J. Gilchrist, Diabetes, $1983,32,839$.

42. L. Bowen, P. P. Stein, R. Stevenson and G. I. Schulman, Metabolism, 1991, 40, 1025.

43. M. K. Lee, P. D. G. Miles, M. Khoursheed, K. M. Gao, A. R. Moossa and J. M. Oletsky, Diabetes, 1994, 43, 1435.

44. M. Khoursheed, P. D. G. Miles, K. M. Gao, A. R. Moossa and J. M. Olefsky, Metabolism, 1995, 44, 1489.

45. A. Y. Chang, B. W. Wyse, B. J. Gilchrist and A. R. Diani, Diabetes, 1983, 32, 830 .

46. Y. Inoue, K. Tanigawa, S. Nakamura, X. Gang, Y. Kato and K. Tamura, Diabetes Res. Clin. Prac., 1995, 27, 19.

47. M. Fuji, R. Takemura, M. Yamaguchi, G. Hasegawa, H. Shigeta and N. Nakano, Metabolism, 1997, 46, 981.

48. T. Fujiwara, M. Wada, K. Fukuda, M. Fukami, S. Yoshioka and T. Yoshioka, Metabolism, 1991, 40, 1213.

49. T. Sohda, Y. Momose, K. Meguro, Y. Kawamatsu, Y. Sugiyama and H. Ikeda, Arz-Forsch/Drug Res., 1990, 40, 37.

50. R. W. Stevenson, N. J. Hutson, M. N. Krupp, R. A. Volkmann, G. F. Holland and J. F. Eggler, Diabetes, 1990. 39, 1218.

51. C. K. Castle, J. R. Colca and G. W. Melchior, Arterioscler. Thromb., 1992, 13, 307.
52. T. Fujiwara, M. Wade, K. Fukuda, M. Fukami, S. Yoshioka, T. Yoshioka and H. Horikoshi, Metabolism, 1991, 40, 1213.

53. G. D. Williams, A. Deldar, W. H. Jordon, C. Gries, C. G. Long and R. D. Dimarch, Diabetes, 1993, 42, 186.

54. N. Gitlin, N. L. Julie, C. L. Spurr, K. N. Lim and H. M. Juarbe, Ann. Int. Med., 1998, 129, 36.

55. B. A. Neuschwander-Tetri, W. L. Isley, J. C. Oki, S. Ramrakhiani, S. G. Quiason, N. J. Phillips and E. M. Brunt, Alnn. Int. Med., 1998, 129, 38.

56. H. Yki-Jarvinen, K. Sahlin, J. M. Ren and V. A. Koivisto, Diabetes, 1990, 39, 157.

57. P. C. Butler, E. J. Kryshak, M. Marsh and R. A. Rizz, Diabetes, 1990, 39, 1373.

58. D. L. Rothman, I. Magnusson and G. Clinic, Proc. Natl. Acad. Sci. USA, 1995, 92, 983.

59. G. W. Cline, K. F. Peterson and M. Krssak, N. Engl. J. Med., 1999, 341, 240.

60. E. M. Wright, E. Truk, B. Zabel, S. Mundlos and J. Dyer, J. Clin. Invest., 1991, 88, 1435.

61. P. R. Shepherd and B. B. Kahn, N. Engl. J. Med., 1999, 341, 248.

62. B. Hulin, P. A. McCarthy and E. M. Gibbs, Curr. Pharm. Des., 1996, 2, 85.

63. C. Hofmann, K. Lorenz and J. R. Colca, Endocrinology, 1991, 129, 1915.

64. T. Ciaraldi and R. R. Henery, Eur. J. Endocrinol., 1997, 137, 610 .

65. D. Szalkowski, S. White-Carington, J. Berger and B. Zhang, Endocrinology, 1995, 136, 1474.

66. M. F. Hirshmn, P. M. Fagnant, E. D. Horton, P. A. King and E. S. Horton, Biochem. Biophys. Res. Commun., 1995, 208, 835 .

67. C. Day, Diabetes Med., 1999, 16, 179.

68. H. Hauner, Diabetes Metab. Res. Rev., 2002, Suppl. 2, 510.

69. B. Desvergne and W. Wahli, Endo. Rev., 1999, 20, 649.

70. G. Xing, L. Zhang, L. Zhang, T. Heynen, T. Yoshikawa, M. Smith, S. Weiss and S. Detera-Waldeigh, Biochem. Biophys. Res. Commun., 1995, 217, 1015.

71. I. Issemann and S. Green, Nature, 1990, 347, 645.

72. F. Chen, S. W. Law and B. W. O'Malley, Biochem. Biophys. Res. Commun., 1993, 619, 671.

73. Y. Zhu, K. Alvares, Q. Huang, M. S. Rao and J. K. Reddy, J. Biol. Chem., 1993, 268, 26817.

74. S. A. Kliewer, B. M. Forman, B. Blumberg, E. S. Ong, U. Borgmeyer, D. J. Mangolsdorf, K. Umesono and R. M. Evans, Proc. Natl. Acad. Sci. USA, 1994, 91, 7355.

75. E. Z. Amri, F. Bonino, G. Alihaud, N. A. Abumrad and P. A. Grimaldi, J. Biol, Chem., 1995, 270, 2367.

76. M. Gotlichetr, E. Widmark, Q. Li and J. A. Gustafsson, Proc. Natl. Acad. Sci. USA, 1992, 89, 4653. 
Ghosh et al. : Advances in the chemistry of thiazolidinediones as antidiabetic agents

77. C. Aperlo, P. Pognonec, R. Saladin, J. Auwerx and K. E. Boulukos, Gene, 1995, 162, 297.

78. A. Schmidt, N. Endo, S. J. Rutledge, R. Vogel, D. Shinar and G. A. Rodan, Mol. Endocrinol., 1992, 6, 1634.

79. T. Sher, H. F. Yi, O. W. McBride and F. J. Gonzalez, Biochemistry, 1993, 32, 598.

80. M. E. Greene, B. Blumberg, O. W. McBride, H. F. Yi, K. Kronquist, K. Kwan, L. Hsieh, G. Greene and S. D. Nimar, Gene Expr., 1995, 4, 281.

81. C. Dreyer, G. Grey, H. Keller, F. Givel, G. Helftenbein and W. Wahli, Cell, 1992, 68, 879.

82. P. Tontonoz, E. Hu, R. A. Graves, A. I. Budavari and B. M. Spiegelman, Genes Dev., 1994, 8, 1224.

83. H. Keller, C. Dreyer, J. Medin, A. Mafoudi, K. Ozato and W. Wahli, Proc. Natl. Acad. Sci. USA, 1993, 90, 2160.

84. T. Lemberger, B. Desvergne and W. Wahli, Ann. Rev. Cell Dev. Biol., 1996, 12, 353.
85. M. Pfahl and F. Chytil, Annu. Rev. Nutr., 1996, 16, 257.

86. A. J. Vidal-Puig, R. V. Considine, M. Jimenez-Linan, A. Werman, W. J. Pories, J. F. Caro and J. S. Fliar, J. Clin. Invest., 1997, 99, 2416.

87. R. F. Kletzien, S. D. Clarke and R. G. Ulrich, Mol. Pharm., 1991, 41, 393.

88. H. Xing, J. P. Northrop, J. R. Grove, K. E. Kilpatrick, J. L. Su and G. M. Ringold, Endocrinology, 1997, 138, 2776.

89. M. Hill, M. Young, C. McCurdy and J. Gimble, Endocrinology, 1997, 138, 3073.

90. Y. T. Kruszynska, R. Mukherjee, L. Jow, S. Dana, J. R. Paterniti (Jr.) and J. M. Olefsky, J. Clin. Invest., 1998, 101, 543.

91. R. F. Kletzien, L. A. Foellmi, P. K. Harris, B. M. Wyse and S. D. Clarke, Mol. Pharm., 1992, 42, 558. 
